\title{
Female Sexuality in the Early Medieval Islamic World: Gender and Sex in Arabic Literature
}

\author{
Pernilla Myrne
}

London: I.B. Tauris, 2020. 228 pages.

In a fascinating passage in his epistle to Abū 'Alī b. al-Ḥārith on differences in character, the polymath Qusțā b. Lūqā (d. 300/912) observes that there are three kinds of sexual preference among people (al-nās): "those who incline to women, those who opt for boys (al-ghilmān) exclusively,

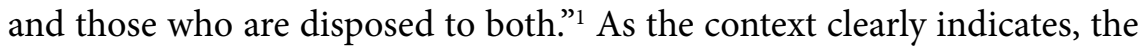
referent of "people" here is, unsurprisingly, adult males: the minority group with whose pens and for whose edification and/or entertainment the overwhelming majority of premodern Arabic texts were composed. This is no less true in the domain of the erotic, as demonstrated by Pernilla Myrne in her outstanding recent monograph on female sexuality in the third and fourth centuries $\mathrm{AH}$, which partly redresses this systematic neglect with its welcome focus on women and their agency. Inevitably, she does so through (meticulous) examination of a range of works of decidedly male provenance. Myrne tracks the relevant debates across literary genres, always with an eye to the representation of women's voices. Chapters are thematically organized and address such topics as female sexuality in medicine, erotology and religious discourse proper (fiqh, hadith, and tafsir) - as in the first section of the book-as well as male-female verbal battles, mujūn, and tribadism $(s a h q)$, in its second part. This is a formidably versatile piece of scholarship. Much attention is paid to the Jawämi cal-ladhdha (c.l. 4/10th century), a veritable encyclopaedia of sex and our earliest extant Arabic erotological work, discussion of which reoccurs throughout. Myrne does very well to highlight as painstakingly as she does both the extra-Islamic origins of much of this discourse in Late Antiquity from Greek and also Sanskrit materials $(3,19-24,51-53$, etc.), along with the variety of viewpoints expressed therein. She is normally very careful not to over-generalize: the physicians of premodern Islamdom generally embraced the view that female orgasm and ejaculation (inzāl) were necessary for conception, though there were exceptions (34). Similarly, the dominant opinion, culturally, supported the notion of women as hypersexual, nine times as libidinous as men, though some occasionally questioned this (60). On Islamic law, Myrne is more given to erroneous overstatement, as in her claim that 
women are incapable of contracting their own marriages (70, against the Hanafīs), ${ }^{2}$ that female circumcision is merely a recommended practice (82, contra the Shāfi îs), ${ }^{3}$ or that jurists equated liwāt to zina (147, against the Hanafīs and Zāhirīs). ${ }^{4}$ These are however minor oversights that do not detract in any significant way from Myrne's accomplishment in this book, which is considerable.

Female Sexuality is a philologist's dream: the woman who faints at climax is a rabukkh (60), we learn; the amorous feminine sounds and movements accompanying coitus are, collectively, ghunj (64, 84-85). Sahq (preferred in this period to sihāq and musähaqa) could be used to refer to any sexual practice involving deliberate clitoral stimulation, not merely of the same-sex kind, as is often assumed (146). Myrne handles a large number of lexically-exacting texts deftly, and must be warmly commended on her knowledge of Arabic. On rare occasions, however, odd choices are made: nikā $h$ is for example consistently rendered as "marriage" or "marital sex" (e.g., 9, 47, 69), notwithstanding the author's extensive treatment of and frequent references to the phenomenon of slave-concubinage. This is more likely a slip than a conscious error.

Theorists of "Islamic medicine" (a term Myrne defends, 3) distinguish themselves from their Late Antique Greek antecedents by their greater focus on female pleasure, along with the relevant pharmacology (14). They universally adopted the two-seed theory of human genesis, while demonstrating awareness of the various Greek and Sanskritic alternatives (22, 51). Phraseology seems to imply that drugs were administered to women, passive consumers of them, while female practitioners of sub-medical arts such as midwifery were held in contempt by (male) professionals (40-41). Already by the period of the Jawāmi al-ladhdha, erotology had come to include elements of medical discourse, in simplified and often imperfectly understood form, especially for the treatment of sexual dysfunction (implied to affect men more so than women, 49). 'Alì b. Nașr al-Kātib, to whom the text is attributed, emphasises the importance of sexual harmony (ittifäq) and the quest for simultaneous climax, which compensates for all other defects in male partners, or so he claims (46, 61-62). Celibacy, no less than overindulgence, is regarded as physically deleterious: in moderation, sex enhances health. And though the physicians of Islamdom did not usually subscribe to the idea of the "wandering womb", they did warn of the dangers of "uterine suffocation" (ikhtināq al-rahm), caused by excess semen or the retention of menses, according to Galen (28). Works of 
erotology devoted the requisite attention to sexual etiquette and technique, often attributed to unknown sages (hukamä) and drawing no doubt on the Kāma Sütra, at least parts of which were available in translation (perhaps via Middle Persian, 57). More interestingly, much Islamicate sexual wisdom is ascribed to older women, including the enigmatic Hubbā al-Madinniyya, to whom our sources give the role of sex-educator extraordinaire in Umayyad Medina (63-64). Not all of the anecdotes told of such women are especially flattering. In both verbal jousting, in which women eloquently defended (for example) their marital rights in the presence of governors and judges, and also in the more narrowly sexual domain, greater outspokenness is invariably attributed to women of the pre- or early Islamic period, or alternatively to slave-concubines (jawārī) later on, as the "ideology of gender" (in Leila Ahmed's phrase) increasingly made itself felt in early Abbasid times (169). It is in instances of women's eloquence (balaghät al-nis $\bar{a})$ that their earthy frankness is in greatest evidence. Myrne's book does much to validate the claims of al-Jāhiz (d. 255/868) in his infamous Risāla fi l-Qiyān that expectations of decorum between the sexes were not always as they later came to be. ${ }^{5}$

Though there are many indications in the sources of women's frankness on matters sexual, as in the copious literature of mujūn (socially and religiously subversive material, usually with erotic or bacchic themes), Myrne notes that women were much more typically the recipients of such treatment than those trafficking in it. Women were parodied much more commonly than they are said to have spoken up, especially by salacious poets like Abū Nuwās (d. 199 or 200/814 or 815) and Ibn al-Hajjāj (d. 391/1001), the pioneers of mujūn and sukhf, respectively $(117-118,142)$. Myrne does not simply assume that all instances of women's speech reflect male ventriloquism; at least in some cases, she suggests, we must not rule out a priori the possibility that the sources convey actual sentiments once expressed by female actors (e.g., 141). One fascinating case is the verse arguments commending sahq (normally, tribadism) against nayk (penetrative sex). Sometimes, it is observed, $s a h q$ is defended as merely an alternative to nayk in the absence of, or given the problems entailed by, male partners, not least of which pregnancy. At other times, tribadism is clearly given preferential treatment and is vaunted as a superior to coitus, as the practice of an exclusive "sisterhood" $(150,164)$. It is here, among other places, that one wishes Myrne had paused to reflect on the possible implications of the sources on this point at greater length. Though clearly familiar with constructionist arguments on sexuality (summarized on 145), the term "homosexual" is 
consistently deployed to render classical Arabic terms, in rather anachronistic fashion. The author nowhere engages this important historiographical debate directly, but is content to simply refer to it without committing herself to either side. This is somewhat unfortunate.

Ultimately, much of the literary production of Abbasid Baghdad reflects straightforwardly "masculinist" norms and priorities. Myrne endorses Shawkat Toorawa's view that the transition from oral (and aural) to literary culture did much to contribute to this (171). The increasingly homosocial atmosphere of Abbasid Baghdad can only have encouraged elite male solidarity. In extreme forms, this manifested in sukhf, which can be considered the sophisticated poetic form of what the current President would term "locker-room talk". As such, Myrne does especially well to highlight women's voices: this is no mean feat, given the nature of the sources. No less significant an achievement is her attention to the manuscript record, which reveals that there are very serious disparities between the few printed editions of extant erotological texts and their manuscript variants (e.g., 203). In this as in other dimensions of Arabic and Islamic Studies, good critical editions remain a desideratum.

Such shortcomings as this book contains are few, and those very minor. Besides the errors noted, it would have been useful to include a more substantial discussion of auto-eroticism, serious scholarly treatment of which is now long overdue. In any case, this remains an impressive and extremely valuable exploration of an understudied subject, one I recommend without reservation to those interested in the history of sexuality, Islamic law and gender, and classical Arabic literature. Its timely appearance has thankfully permitted me to incorporate it into this semester's teaching.

Omar Anchassi

Early Career Fellow in Islamic Studies University of Edinburgh, Edinburgh, UK

\section{Endnotes}

1. R.P. Paul Sbath, "Le Livres Des Caractères de Qosṭā ibn Loūqā: Grand Savant et Célèbre Médecin Chrétien au IX Siècle" [critical edition and French translation], Bulletin de L'Institut d'Égypte 23 (1940-1): 103-167 (at 112).

2. E.g. al-Sarakhsī (d. 490/1097), al-Mabsūțt (Beirut: Dār al-Ma`rifa, 1989, repr. of the 1331 Dār al-Sa āda edn.), 5:10. 
3. E.g., al-Nawawī (d. 676/1277), Kitāb al-Majmū' ${ }^{c}$ Sharh al-Muhadhdhab li-lShirāzī, ed. Muhammad Najīb al-Mutịīi (Jeddah: Maktabat al-Irshād, n.d.), 1:349.

4. E.g., al-Marghīnānī (d. 593/1197), al-Hidāya bi-Sharh Bidāyat al-Mubtadī, ed. $\mathrm{Na}^{\mathrm{c} i ̄ m}$ Ashraf Ahmad (Karachi: Idārat al-Qur’ān wa-l-'Ulūm al-Islāmiyya, 1417), 4:104-105. For the Zāhirīs, see Ibn Hazm (d. 456/1064), al-Muḥallā bi-l-Āthār, eds. Khālid al-Rabbāṭ et al. (Beirut: Dār Ibn Hazm, 2016), 16:449.

5. The Epistle on Singing-Girls of Jähiz, ed. and trans. AFL Beeston (Warminster: Aris and Phillips, 1980), 19-22.

doi: 10.35632/ajis.v37i1-2.726 